\title{
Elastisitas Transmisi Harga Daging Kerbau Rawa di Desa Sapala Kecamatan Paminggir Kabupaten Hulu Sungai Utara
}

\section{(Price Elasticity Transmition of Swamp Buffalo in The Sapala Village Paminggir District Hulu Sungai Utara Regency)}

\author{
Miranda Romaully Br. Sitanggang ${ }^{1)}$ \& Firdaus ${ }^{2)}$ \\ Program Studi Agribisnis, Sekolah Tinggi Ilmu Pertanian Amuntai \\ ${ }^{1)}$ miranda.rsd2203@gmail.com \\ 2)firdaussapala@yahoo.com
}

\begin{abstract}
ABSTRAK
Penelitian ini mengevaluasi aspek pemasaran daging kerbau rawa yang diadakan di Desa Sapala Kecamatan Paminggir Kabupaten Hulu Sungai Utara. Desa ini dipilih karena banyak pedagang dan peternak kerbau rawa. Tujuan penelitian adalah untuk mengidentifikasi elastisitas harga kerbau rawa transmisi di daerah penelitian. Elastisitas transmisi harga pada pemasaran daging kerbau di Desa Sapala Paminggir Hulu, Sungai Utara adalah 3.089. Elastisitas transmisi harga mewakili kurang dari satu (Et $<1)$, yang berarti bahwa perubahan $1 \%$ pada harga di tingkat konsumen akan menyebabkan perubahan harga sebesar 0,281\% di tingkat produsen. Ini menunjukkan harga transmisi yang relatif tidak elastis. Jadi perubahan harga di tingkat konsumen akan memberikan sedikit perubahan pada harga petani, itu berarti bahwa pemasaran daging rawa kerbau tidak efisien.
\end{abstract}

Kata kunci: Kerbau, rawa, transmisi, elastisitas, pemasaran.

\section{ABSTRACT}

This study evaluating the marketing aspect swamp buffalo meat is held in the Sapala village Paminggir District of Hulu Sungai Utara Regency. This village was chosen because there were many swamp buffalo traders and breeders. The research goal is to identify the elasticity of price transmission swamp buffalo in the study area. The elasticity of price transmission on buffalo meat marketing in the village Sapala Paminggir Hulu subdistrict North River is 3,089. Elasticity of price transmission represents less than one $(E t<1)$, meaning that a $1 \%$ change in the price at the consumerlevel will lead to a change in price by $0.281 \%$ at the producer level. This shows the price is relatively inelastic transmission. So the price changes at the consumer level will provide a little change in farmer prices it's mean that marketing of buffalo swamp meat is not efficient.

Keywords: Buffalo, swamp, elasticity, transmission, marketing.

\section{PENDAHULUAN}

Kalimantan Selatan merupakan wilayah di Indonesia yang memiliki lahan rawa cukup luas. Luas wilayah Kalimantan Selatan 3.753.052 ha, dengan luasan lahan rawa sekitar 181.169 ha atau $4,83 \%$ dari luas wilayah yang dimiliki merupakan potensi yang prospektif dalam rangka pengembangan dan melestarikan ternak kerbau rawa di Kalimantan Selatan. Salah satu kabupaten dengan kondisi wilayahnya sebagian besar berupa lahan rawa adalah Kabupaten Hulu Sungai Utara.

Selain menjadi alternatif untuk memenuhi kecukupan pangan pokok beras terutama di musim kemarau, lahan rawa juga menjadi sumber alternatif pangan hewani dari kerbau rawa. Peternakan kerbau rawa ini dapat membantu mewujudkan ketahanan pangan dan mengentaskan kemiskinan di daerah lahan rawa. Peternakan kerbau rawa diharapkan dapat menjadi alternatif sumber penghasilan dan menambah penghasilan penduduk setempat yang mengusahakannya.

Kerbau rawa dengan sistem budidayanya yang bersifat penggembalaan lepas mengakibatkan struktur daging yang dihasilkan mengandung lemak lebih rendah dari sapi yang digemukkan dalam kandang. Hal ini sama dengan daging ayam kampung dibandingkan dengan daging ayam ras broiler. Sehingga daging kerbau menjadi alternatif sumber protein rendah lemak. 
Populasi kerbau rawa terbesar di Kabupaten Hulu Sungai Utara adalah di Kecamatan Paminggir terutama di Desa Sapala yang sangat didukung oleh keadaan wilayahnya yang dikelilingi oleh air dan pakan hijauan yang tersedia, sehingga sangat cocok sekali untuk pemeliharaan dan pengembangan hewan ternak kerbau rawa. Banyaknya ternak kerbau rawa untuk wilayah Kabupaten Hulu Sungai Utara yang dirinci pada tiap-tiap kecamatan dari tahun 2008-2012 dapat dilihat melalui Tabel 1 berikut.

Tabel 1. Banyaknya ternak kerbau di Kabupaten Hulu Sungai Utara yang dirinci tiap kecamatan dari tahun 2008-2012

\begin{tabular}{clccccc}
\hline \multirow{2}{*}{ No } & \multirow{2}{*}{ Kecamatan } & 2008 & 2009 & 2010 & 2011 & 2012 \\
\cline { 3 - 7 } & & 8.206 & - & - & - & - \\
\hline 1 & Danau Panggang & - & 8.409 & 8.482 & 7.435 & 8.169 \\
2 & Paminggir & - & - & - & 2 & 2 \\
3 & Babirik & 99 & 100 & 115 & 164 & 75 \\
4 & Sungai Pandan & - & - & - & - & - \\
5 & Sungai Tabukan & 3 & 4 & - & 48 & 63 \\
6 & Amuntai Selatan & 85 & 86 & 89 & 121 & 76 \\
7 & Amuntai Tengah & - & - & - & 11 & 11 \\
8 & Banjang & - & - & - & 30 & 8 \\
9 & Amuntai Utara & - & - & - & 2 & - \\
10 & Haur Gading & &
\end{tabular}

Sumber : Dinas Perikanan dan Peternakan Kabupaten Hulu Sungai Utara (2014).

Dapat di lihat pada Tabel 1 populasi kerbau rawa terbanyak ialah terdapat pada Kecamatan Paminggir. Populasi kerbau rawa yang besar di Kecamatan Paminggir sangat didukung oleh keadaan wilayahnya yang dikelilingi oleh air dan pakan hijauan yang tersedia, sehingga sangat cocok sekali untuk pemeliharaan dan pengembangan hewan ternak kerbau rawa.

Terkait keberadaan kerbau rawa sebagai komoditi ternak unggulan di Desa
Sapala Kecamatan Paminggir Kabupaten Hulu Sungai Utara, aktivitas pendistribusian/ tataniaga kerbau rawa dari produsen hingga ke konsumen haruslah dilakulan secara efektif dan efisien. Karena kedua hal tersebut merupakan kunci utama ketersediaan daging kerbau di pasaran. Mengenai harga daging kerbau ditingkat produsen dan konsumen dapat dilihat pada Tabel 2 berikut.

Tabel 2. Harga daging kerbau di Kabupaten Hulu Sungai Utara pada tingkat konsumen dan produsen dari bulan Juni 2013 - Juni 2014

\begin{tabular}{clcccc}
\hline \multirow{2}{*}{ No } & \multicolumn{2}{c}{ Bulan/ Tahun } & \multirow{2}{*}{ Satuan } & \multicolumn{3}{c}{ Harga di Tingkat (Rp.) } \\
\cline { 4 - 6 } & & $\mathrm{Kg}$ & 91.000 & Grosir & Konsumen \\
\hline 1 & Juli 2013 & $\mathrm{Kg}$ & 94.000 & - & 95.000 \\
2 & Agustus 2013 & $\mathrm{Kg}$ & 94.000 & - & 100.000 \\
3 & September 2013 & $\mathrm{Kg}$ & 95.000 & - & 100.000 \\
4 & Oktober 2013 & $\mathrm{Kg}$ & 98.000 & - & 100.000 \\
5 & November 2013 & $\mathrm{Kg}$ & 98.000 & - & 105.000 \\
6 & Desember 2013 & $\mathrm{Kg}$ & 100.000 & - & 105.000 \\
7 & Januari 2014 & $\mathrm{Kg}$ & 105.000 & - & 110.000 \\
8 & Februari 2014 & $\mathrm{Kg}$ & 105.000 & - & 110.000 \\
9 & Maret 2014 & $\mathrm{Kg}$ & 105.000 & - & 110.000 \\
10 & April 2014 & $\mathrm{Kg}$ & 105.000 & - & 110.000 \\
11 & Mei 2014 & $\mathrm{Kg}$ & 105.000 & - & 110.000 \\
12 & Juni 2014 &
\end{tabular}

Sumber : Dinas Perikanan dan Peternakan Kabupaten Hulu Sungai Utara (2014). 
Pada Tabel 2 di atas diketahui perkembangan harga daging kerbau di Kabupaten Hulu Sungai Utara pada tingkat produsen sampai ke konsumen dalam kurun waktu 1 tahun (dari bulan Juli 2013 sampai bulan Juni 2014). Berdasarkan data tersebut harga tertinggi daging kerbau ditingkat produsen sebesar Rp. 105.000,-/ kg dan harga tertinggi ditingkat konsumen sebesar Rp. $110.000,-/ \mathrm{kg}$ yang berlaku dari bulan Februari 2014 sampai dengan bulan Juni 2014.

$$
\text { Mekanisme dan pola }
$$
distribusi/pemasaran kerbau rawa di Desa Sapala Kecamatan Paminggir menghasilkan tingkatan harga-harga keuntungan pasar (margin) dan elastisitas transmisi pada berbagai tingkatan lembaga yang terlibat di dalam tataniaga tersebut. Dengan demikian, lembaga yang terlibat dalam penyampaian barang dan jasa pertanian hingga konsumen berperanan penting dalam penentuan harga dan ketersediaan pasokan di pasaran. Selain itu keberadaan usaha ternak kerbau rawa diharapkan mampu meningkatkan pendapatan masyarakat melalui keterkaitan alam yang saling menguntungkan dan berintregasi. Terciptanya usaha ternak kerbau rawa akan menciptakan kesejahteraan masyarakat secara mandiri. Dengan segala keterbatasan peternak, perlu dikembangkan sebuah sistem peternakan yang berwawasan ekologis, ekonomis, dan berkesinambungan sehingga peternakan industri dan peternakan rakyat dapat mewujudkan ketahanan pangan dan mengantasi kemiskinan (Dinas Peternakan, 2011). Penelitian ini ingin mengetahui nilai elastisitas transmisi harga kerbau rawa di daerah penelitian. Hasil penelitian ini dapat digunakan sebagai salah satu indikator efisiensi pemasaran daging kerbau rawa yang berasal dari Desa Sapala Kecamatan Paminggir Kabuaten Hulu Sungai Utara.

\section{METODE PENELITIAN}

Penelitian ini dilaksanakan di Desa Sapala Kecamatan Paminggir Kabupaten Hulu Sungai Utara. Penelitian dilaksanakan dari bulan Desember 2014 - Maret 2015.
Pengumpulan data dengan metode wawancara terhadap konsumen daging kerbau sebanyak 30 orang yang ditentukan dengan non probably sampling yakni menentukan pembeli untuk data harga konsumen kemudian menelusuri hingga produsen daging kerbau ditingkat petani untuk harga produsen.

\section{Metode Analisis Data}

Elastisitas transmisi harga digunakan untuk menjelaskan perbandingan persentase perubahan harga di tingkat pengecer dengan persentase perubahan harga di tingkat produsen. Elastisitas transmisi ini mengambarkan bagaimana harga yang dibayarkan konsumen akhir ditransmisikan kepada produsen. Rumus elastisitas transmisi (Et) adalah sebagai berikut (Sudiyono, 2004):

$$
\mathrm{Et}=\mathrm{dPr} / \mathrm{dPf} . \mathrm{Pf} / \mathrm{Pr}
$$

Keterangan :

Et : elastisitas transmisi harga

$\mathrm{Pr} \quad$ : harga di tingkat konsumen

Pf : harga di tingkat petani produsen/peternak

$\mathrm{dPr}$ : perubahan harga di tingkat konsumen dPf : perubahan harga di tingkat produsen/peternak

Harga daging kerbau rawa di tingkat konsumen atau pengecer merupakan penjumlahan harga di tingkat peternak dengan marjin tataniaganya. Jika Harga di tingkat peternak diasumsikan sebagai fungsi linear dari harga pengecer maka elastisitas harga dapat juga dicari dengan menggunakan logaritma dari fungsi tersebut:

$$
\begin{aligned}
& \mathrm{Pf}=\mathrm{a}+\mathrm{bPr} \\
& \ln \mathrm{Pf}=\ln \mathrm{a}+\mathrm{b} \ln \mathrm{Pr}
\end{aligned}
$$

dimana :

$\mathrm{b}=$ elastisitas transmisi harga

Selanjutnya Fungsi Elastisitas transmisi harga tersebut diestimasi dengan metode Ordinary Least Square (OLS) menggunakan SPSS 20. Kemudian dilakukan uji hipotesis dengan uji t jika sesuai harapan maka hipoteis alternatif yang diterima dengan ketentuan jika elastisitas transmisi bernilai kurang dari satu $(\mathrm{Et}<1)$, artinya perubahan harga $1 \%$ di tingkat konsumen akan mengakibatkan perubahan harga yang 
kurang dari $1 \%$ di tingkat produsen; $\mathrm{Et}=1$, berarti perubahan harga $1 \%$ di tingkat konsumen mengakibatkan perubahan 1\% ditingkat produsen, sedangkan Et $>1$, berarti perubahan harga $1 \%$ di tingkat konsumen mengakibatkan perubahan harga $>1 \%$ di tingkat produsen.

Pada $\mathrm{Et}=1$, maka keadaan pasar berjalan dengan efisien, sedangkan Et $<1$ atau Et $>1$, maka keadaan pasar tidak berjalan dengan efisien (tidak bersaing sempurna). Elastisitas transmisi merupakan salah satu indikator untuk mengetahui intensiatas persaingan dengan melihat apakah informasi sampai di tingkat konsumen sampai kepada produsen.

Hubungan elastisitas antara harga yang diterima petani produsen dengan harga yang dibayar oleh konsumen sangat tergantung pada struktur pasar yang menghubungkannya. Keterpaduan pasar dideteksi dengan keterkaitan harga antar pasar, karena harga mengandung informasi tentang kondisi pasar dan sekaligus menjadi salah satu variabel penyesuaian keseimbangan pasar. Adanya peningkatan harga, berarti telah terjadi kelebihan permintaan dan nilai peningkatan harga tersebut merupakan mekanisme menuju tercapainya keseimbangan baru. Elastisitas trasmisi harga digunakan untuk mengetahui hubungan antara harga di tingkat petani dengan harga di tingkat pedagang pengecer (Sudiyono, 2004).

\section{HASIL DAN PEMBAHASAN}

\section{Elastisitas Transmisi Harga Daging Kerbau}

Elastisitas transmisi harga pada ruang lingkup kajian dalam penelitian ini digunakan untuk menjelaskan perbandingan persentase perubahan harga di tingkat pedagang besar dengan persentase perubahan harga di tingkat produsen atau peternak kerbau. Analisis transmisi ini memberikan gambaran bagaimana harga yang dibayarkan konsumen akhir ditransmisikan kepada produsen.

Tabel 1. Hasil estimasi fungsi logaritma harga di tingkat peternak kerbau rawa di Desa Sapala Kecamatan Paminggir Kabupaten Hulu Sungai Utara 2014

\begin{tabular}{ccccccc}
\hline No & Keterangan & $\mathrm{R}^{2}$ & F hitung & peluang & t hitung & peluang \\
\hline 1 & Fungsi ln Pf & 0.144 & 4.71 & 0.039 & & \\
2 & $\mathrm{a}$ & & & & 8.291 & 0.000 \\
3 & Et & & & 0.281 & 0.039 \\
\hline
\end{tabular}

Berdasarkan hasil perhitungan di atas diketahui nilai elastisitas transmisi harga pemasaran daging kerbau di Desa Sapala Kecamatan Paminggir Kabupaten Hulu Sungai Utara adalah 0.281. Elastisitas transmisi harga untuk lembaga pemasaran tersebut bernilai kurang dari satu $(\mathrm{Et}<1)$, artinya perubahan harga $1 \%$ di tingkat konsumen akan mengakibatkan perubahan harga sebesar $0.281 \%$ di tingkat produsen.

Kecilnya nilai elastisitas transmisi harga menunjukkan jika terjadi kenaikan harga di tingkat konsumen missal karena kenaikan permintaan maka peternak tidak cukup informasi atau informasi diterima lambat oleh peternak. Sehingga yang menikmati dari kenaikan harga ini lebih pada pedagang pengecer. Peternak lambat merespon kenaikan harga ini sehingga tidak sempat menaikan harga di tingkat peternak. Menyebabkan dengan harga yang sama di tingkat peternak lembaga pemasaran menikmati share margin yang lebih besar. Jika Elastisitas transmisi sama dengan satu maka informasi kenaikan harga juga sampai pada peternak sehingga sama-sama menikamati manfaat dari adanya kenaikan harga. Selanjutnya peternak akan menambah produksi ketersediaan daging kerbau rawa akanmemenuhi peningkatan permintaan sehingga harga kembali pada keseimbangan dan konsumen juga menjadi puas.

Nilai Koefisien Determinasi $\left(\mathrm{R}^{2}\right)$ yang kecil sebesar 0.144 menunjukkan 
bahwa keragaan variabel harga konsumen hanya memeberikan kontribusi penentu bagi keragaan harga peternak sebesar $14,4 \%$ sisanya oleh variabel lain dan error term yang tidak dimasukkan dalam model regresi. Hal ini sesuai dengan teori bahwa harga jual ditentukan oleh banyak variabel seperti jumlah permintaan, ketersedian barang dalam hal ini daging kerbau rawa, biayabiaya dalam kegiatan pemasaran serta faktor social ekonomi lain. Tidak dimasukkannya faktor-faktor lain dengan asumsi cateris paribus dan penyederhanaan model.

Nilai $\mathrm{F}$ hitung sebesar 4,71 dengan nilai peluang 0,039 menunjukkan tingkatkesalahan lebih kecil dari tingkat $\alpha=$ 0.05 sehingga dengan uji $F$ hasil regresi menunjukkan bisa dilanjutkan pengujian hipotesis dengan uji t. Hasil $t$ hitung menunjukkan bahwa angka Et signifikan karena nilai peluangnya 0,039 juga lebih kecil dari tingkat $\alpha=0.05$ sehingga besaran elastisitas transmisi bisa digunakan untuk menarik kesimpulan penelitian.

Besaran elastisitas transmisi harga menyatakan besarnya perubahan nilai harga di tingkat pedagang pengecer $(\mathrm{dPr} / \mathrm{Pr})$ dan perubahan harga di tingkat produsen atau peternak kerbau rawa (dPf/Pf) di desa Sapala. Nilai elastisitas transmisi yang kecil menunjukkan bahwa informasi harga di tingkat konsumen belum dapat tersampaikan dengan baik ke tingkat peternak. Hal ini berarti pemasaran daging kerbau rawa di Desa Sapala belum efisien.

Penyebab tidak efisiennya pemasaran dapat disebabkan distribusi daging rawa dikuasai oleh pedagang besar yang memiliki kemampuan modal cukup besar untuk membiayai pemotongan kerbau dan pengangkutan yang relatif mahal. Namun
Efisien tidaknya pemasaran tidak hanya dilihat dari intensitas persaingan tetapi juga harus dilihat dari indikator lain seperti share margin yang adil, tersedianya sarana transportasi yang memadai. Hasil penelitian ini hanya melihat intensitas persaingan dari segi ketersedian informasi harga atau transmisi informasi harga di tingkat konsumen kepada produsen.

\section{KESIMPULAN}

Nilai elastisitas transmisi harga $(\mathrm{Et})$ pemasaran daging kerbau di Desa Sapala Kecamatan Paminggir Kabupaten Hulu Sungai Utara adalah 0,281. Elastisitas transmisi pemasaran tersebut bernilai kurang dari satu $(\mathrm{Et}<1)$, artinya perubahan harga $1 \%$ di tingkat konsumen akan mengakibatkan perubahan harga kurang dari $1 \%$ di tingkat produsen. Hal ini menunjukkan masih belum efisiennya pemasaran daging kerbau dari Desa Sapala kepada konsumen di kabupaten Hulu Sungai Utara.

\section{DAFTAR PUSTAKA}

Dinas Peternakan. 2011. Sekilas Kerbau Rawa Di Kabupaten.

Hulu Sungai Utara. Dinas Peternakan Kabupaten Hulu Sungai Utara. Amuntai.

Profil Desa Sapala. 2013. Kecamatan Paminggir, Kabupaten Hulu Sungai Utara. Amuntai.

Sudiyono, A. 2004. Pemasaran Pertanian. Penerbit Universitas Muhammadiyah Malang. Malang. 